\title{
Fintech and Sustainability: Do They Affect Each Other?
}

\author{
Cristina Chueca Vergara * and Luis Ferruz Agudo
}

Accounting and Finance Department, Faculty of Economics and Business, University of Zaragoza, 50005 Zaragoza, Spain; lferruz@unizar.es

* Correspondence: 720270@unizar.es

check for updates

Citation: Chueca Vergara, C.; Ferruz Agudo, L. Fintech and Sustainability: Do They Affect Each Other?. Sustainability 2021, 13, 7012. https:// doi.org/10.3390/su13137012

Academic Editors: Salvador

Cruz Rambaud, Joaquín

López Pascual and Bruce Morley

Received: 14 April 2021

Accepted: 19 June 2021

Published: 22 June 2021

Publisher's Note: MDPI stays neutral with regard to jurisdictional claims in published maps and institutional affiliations.

Copyright: (c) 2021 by the authors. Licensee MDPI, Basel, Switzerland. This article is an open access article distributed under the terms and conditions of the Creative Commons Attribution (CC BY) license (https:// creativecommons.org/licenses/by/ $4.0 /)$.

\begin{abstract}
Current concerns about environmental issues have led to many new trends in technology and financial management. Within this context of digital transformation and sustainable finance, Fintech has emerged as an alternative to traditional financial institutions. This paper, through a literature review and case study approach, analyzes the relationship between Fintech and sustainability, and the different areas of collaboration between Fintech and sustainable finance, from both a theoretical and descriptive perspective, while giving specific examples of current technological platforms. Additionally, in this paper, two Fintech initiatives (Clarity AI and Pensumo) are described, as well as several proposals to improve the detection of greenwashing and other deceptive behavior by firms. The results lead to the conclusion that sustainable finance and Fintech have many aspects in common, and that Fintech can make financial businesses more sustainable overall by promoting green finance. Furthermore, this paper highlights the importance of European and global regulation, mainly from the perspective of consumer protection.
\end{abstract}

Keywords: Fintech; sustainability; green investment; socially responsible investing (SRI); green finance; greenwashing; digitization

\section{Introduction}

Currently, more and more new issues are emerging that affect financial management. These are the consequence of increasing customer concerns for sustainability and respect for the environment in the goods and services they purchase and consume, as well as with growing digitization.

Important examples of these issues are corporate social responsibility (CSR) and environmental, social, and governance (ESG) factors. Similarly, the 2030 Agenda for Sustainable Development Goals (SDGs) promoted by the United Nations plays an important role in combating climate change.

The growing awareness of global warming and its negative impact on the planet means that customers are increasingly demanding ecological or environmentally friendly products for a more sustainable lifestyle. Customers, investors, and public administrations are exerting increasing pressure on organizations to obtain more transparent information on the environmental impact of their activities. For example, Nielsen Media Research reports that " $66 \%$ of global consumers" (and 73\% of millennials) [1] "are willing to pay more for environmentally friendly products. Thus, when these customers perceive firms to be socially responsible, they may be more willing to buy the products of these firms, and at a higher price" [2].

Hence, firms strive to differentiate their products and their brands from their competitors, setting up "green marketing" campaigns and modernizing their technologies. In addition, they compete for consumers' approval by advertising their products as environmentally friendly. These green marketing initiatives "are helpful to consumers by letting them know which products possess said green properties, but only if the claims in advertisements and product descriptions are honest and accurate" [3]. 
On the one hand, the innovations of green technologies provide additional financial resources, because green investment is an alternative option for financing such modernization. On the other hand, the existing competition for obtaining green-oriented investors and consumers leads to the use of "greenwashing" by companies as an unfair marketing instrument [4].

Greenwashing is a set of deceptive behaviors or practices that deliberately mislead consumers about the ecological activities of an organization or the environmental benefits of a given product, which appear to be sustainable but are not. Such practices are conducted using ambiguous words and images in the description of the environmental features of a product or via vague, unprovable, and even false ecological claims, exaggerating the ecological features of the product by omitting or masking important information, or by presenting data in a misleading way.

In other words, "greenwashing" is an attempt by a company to make its products appear environmentally friendly when, in reality, they are not. The concept was created by Jay Westerveld in 1986 and can be defined as "the intersection of two firm behaviors: poor environmental performance and positive communication about environmental performance" [5].

Certain factors, such as $\mathrm{CO} 2$-neutral certification, contribute to this phenomenon, as they allow a highly polluting company to appear ecologically sound by attaching a green label with this kind of certification for its products. However, such labels are not always meaningful, and it is important to distinguish reliable companies and those providing independent verification with standardized protocols from those that are not.

Greenwashing practices undermine the credibility of any corporate social responsibility (CSR) endeavor, since they threaten to negate the effects of communicating a company's efforts to act in an environmentally and socially responsible manner. At the same time, they threaten to erode customer confidence. "Whereas reporting about corporate social responsibility (CSR) initiatives is a reasonable and even often economically sound thing to do, greenwashing threatens to dilute the entire CSR movement, thereby reducing the pressure on companies to act economically and socially responsibly". Moreover, we must consider that "greenwashing is hard to detect with reasonable effort, so it goes unnoticed most of the time", and "even if greenwashing is detected, it is not perceived as very negative" [6].

As a result, "consumers increasingly mistrust statements regarding CSR, as they suspect they are being lied to, or important information is being withheld". Moreover, because greenwashing is not often detected, it "thereby does not have any negative consequences for the respective manufacturer or vendor" [3].

In addition, concern for the environment and sustainability not only affects consumers but also investors, who increasingly consider certain non-financial attributes in their investments, such as environmental, social, and governance (ESG) criteria. Related to this is socially responsible investment (SRI), which "appeals to investors who wish to go beyond the financial utility of their investments and derive non-financial utility by investing in companies that reflect their social values" [7].

It must also be considered that "investors are increasingly willing to incorporate into their investment decisions not only financial criteria (returns and risk), but also the non-financial attributes of SRI" [8] and that "country-specific factors tend to affect the relationship between corporate social and financial performance" of a company. Another issue to bear in mind is that "there is some evidence that the label "socially responsible" might be more a marketing strategy, thus not assuring investors that an SRI fund is really socially responsible" [8].

Related to the above are "green bonds", a type of fixed-income instrument applied exclusively to the partial or full financing or refinancing of eligible green projects, whether new and/or existing, which are in line with the four core components of Green Bond Principles (GBP) [9]. There are different kinds of green bonds on the market, and in 2019, $\$ 257.7$ billion in green bonds were issued, a 51\% increase on the 2018 figure and constituted a new world record [9]. 
Furthermore, as the supply and demand for sustainable financing have evolved, several providers of (new) products and services have emerged over recent years. These providers offer solutions for the (new) needs or demands set out in the new sustainability paradigm. These new products and services have emerged in support of the ecological transition process to promote the link between sustainability and economic and financial activities. Their various objectives include increasingly available information on climate; support for the design of more sustainable products and services; and the improvement of public transparency and information. For example, in Spain, the Fundación Ecología y Desarrollo, or ECODES (Ecology and Development Foundation), offers a climate-change risk assessment model that enables the financial sector to assess the predisposition to risks and opportunities of its credit and investment portfolios. This service was designed to be used by the banking sector, but is also useful for other financial sector entities, such as fund managers, investment advisers, insurance companies, and public sector entities in charge of socio-economic planning and development [10]. On a global level, the organization that conducts this kind of activity is the Intergovernmental Panel on Climate Change (IPPC), the United Nations body for assessing the science related to climate change [11].

Notwithstanding the above, digitization, internationalization, and risk analysis must not be forgotten. These are some of the most widespread business practices in the current era and are being increasingly used in the financial field, in general, and financial management, in particular.

Within the digital and technological context, the special importance of so-called "Fintech" must be highlighted. Fintech refers to the latest technologies used in innovative financial products and services. This is one of the most important new markets in recent times, and this cutting-edge business model has great potential for the collaboration of different types of institutions, both public and private.

Fintech [12] comprises digital innovation and modern technology to improve, develop, and automate financial services and is used to assist and support firms, investors, and customers in managing their financial activities using specialized applications and software [13]. Fintech generally attracts customers with more user-friendly, efficient, transparent, and automated products and services [14].

More specifically, Fintech includes new applications, processes, products, and business models in the area of financial services, consisting of one or more financial services, mostly or entirely provided over the internet, "simultaneously by various independent service providers, typically including at least one licensed bank or insurance company" [15]. Some of the financial services provided may include investment advice (robo-advising), credit decisions, asset trading, digital currencies, automatic transactions, payment settling, crowdfunding, person-to-person transactions (P2P), and smartphone wallets [15].

The current era in the evolution of Fintech is called "Fintech 3.0", which began in 2008, and whose first years were dominated by the global crisis and financial turmoil, when there was a loss in trust in the banking system. Then, technological firms began to operate using peer-to-peer networks outside the regulatory framework (in fact, 2000 of these platforms were developed in China) [16] and to apply new technologies in the financial markets, changing the way of doing business in all financial sectors [17]. This development is ongoing [17], and banks today are being displaced by technological firms and start-ups at a rapid pace [16]. According to Moro-Visconti, Cruz Rambaud, and López Pascual, some of the reasons for this rapid evolution of Fintech are the sharing and circular economy, favorable regulation, and information technology [14].

Initially, the largest Fintech market was developed in the US, followed by the UK (the most important Fintech market in Europe) [18]. The European and American Fintech properties and background differ from the Asian Fintech, which specifically offers solutions for a lack of existing banking infrastructure [19].

Establishing Fintech is easier in well-developed economies, because the infrastructure and market regulations are there already. This infrastructure and affordable technology are critical to creating sustainable, unique financial innovation, although Fintech development 
often occurs in economies where access to loans is more difficult [18]. In fact, "scalability plays a key role in new financial start-ups, and Fintech's profits remain quite small until a scalable number of customers has been convinced. This scalability of processes can be achieved by platform creation, which leads to economies of scale and, hence, reduced costs, and user networks being built" [17]. Additionally, "financial inclusion can positively affect the economy in terms of poverty reduction and economic growth, and innovations in digital finance can positively influence banks' performance and profitability" [17,20]. "Fintech's key advantages are greater control of customers' personal finance, rapid financial decision-making, and the ability to make and receive payments within seconds, although this results in a trade-off between efficiency and (data) security" [17,20]. Therefore, "from a regulatory perspective, the greatest challenges are then to ensure both consumer and investor protection and to guarantee financial stability" [17].

Fintech "allows performing business transactions from anywhere at any time, which gives flexibility to all actors" [13]. Companies that have developed Fintech have more innovative methods of extending banking services to customers and investors through cellphone apps, with increased flexibility and efficiency of financial services, and with the promise of saving time and costs through the use of digital technologies [13]. Furthermore, Fintech is a key driver "for financial development, inclusion, social stability, and integrity, and consequential sustainable development through building an infrastructure for an innovative digital financial ecosystem" [12]. It makes financial services more accessible, efficient, and affordable for customers and changes the ways of providing traditional services, representing the digitization of the financial industry [17].

"Fintech is also regarded as an engine for sustainable economic growth as a new industry having different characteristics from the traditional financial industry". With high expectations for growth, global Fintech investments have greatly increased. In fact, KPMG reported that "global investment in Fintech has doubled more than six times, from $\$ 18.9$ billion to $\$ 111.8$ billion between 2013 and 2018" [21].

Moro-Visconti, Cruz Rambaud, and López Pascual state that, "despite the young age of Fintech, many of these firms are experiencing significantly faster growth than their traditional financial services peers" [14]. In addition, since they belong to a growing industry and not a mature one, they are slightly more volatile than IT firms and much more volatile than traditional, established banks. This higher volatility was reflected in March 2020 in a much steeper fall than banks, followed by a more sustained recovery, "incorporating the digital resilience typical of most technological firms". "Whereas Fintech and technology stocks have fully recovered from the negative peak of 23 March 2020, banks (as of 30 June 2020) were still some 25\% below their pre-COVID-19 prices" [14].

Experts claim that "Fintech has the potential to disrupt and transform the financial sector by making it more transparent, secure, and less expensive" [15], as financial products traditionally offered by licensed credit institutions (payment services and loans, among others) are now also offered by Fintech. It supports a greater diversity of products and providers, and offers improved risk management, with its ability to obtain instant customer feedback and use it to power real-time adjustments in the services offered [14].

However, for the last decade, large financial institutions have increased their interest, along with investments, in Fintech innovations, to the point that, in 2019, most competitive financial institutions considered Fintech to be their major investment [15]. Both operate in the same (financial) market and sometimes share customers [14]. In fact, it is expected that financial institutions will be able to reduce their costs and increase customer inclusion with the help of Fintech, leading to an increase in profits. Thus, Moro-Visconti, Cruz Rambaud, and López Pascual also believe that Fintech will "disrupt and reshape the financial industry by cutting costs, improving the quality of financial services, and creating a more diverse and more stable financial landscape" [14]. It will also lead to greater access to finance and investment, which offers great potential to transform not only finance but economies and societies, in general, through financial inclusion and sustainable, balanced development [14]. 
At present, new sector entrants aim to develop new, more customer-centric and digitally enabled services and, with key technology evolving "rapidly alongside changing consumer needs, industry leaders will be forced to compete with start-ups and tech companies for the new business models" [15]. Market leaders can benefit from this technological disruption, since "they have more financial resources and greater economies of scale for introducing new lines of business, compared to competitors", and the "amount of resources allocated to R\&D\&I can increase the agility of market leaders to mitigate damage from potential external disruptive innovations" [15].

"Fintech's technological advantage over traditional financial institutions is the key driver of success and competitive advantage. Fintech's technologies should have a valueadded for the customer ("customer-centricity"), and mobile and data-based services can enhance efficiency. Another characteristic of Fintech is its ability to connect people or services through platforms" [17].

"Nowadays, customers choose the best service from a variety of companies, and traditional financial institutions increase their investments in external financial start-ups to stay competitive" [17]. This type of collaboration between Fintech and traditional institutions can take different forms, such as partnering, outsourcing, or investment as a venture capitalist [17].

Banks have changed their role in funding new financial technology entrepreneurs, since they now serve as a major provider of funding for young companies. Thanks to digital technology development, they have shifted from traditional money-lending activities to become stakeholders in Fintech and, therefore, equity investors [17]. Some authors [17] recommend "collaboration and trust-based relationships to mutually benefit Fintech and established banks", as Fintech "must be operated by experienced founders with a clear vision", because "investors expect founders to run the business successfully from Day 1" [17]. Moro-Visconti, Cruz Rambaud, and López Pascual state that all these ideas can be summarized by the word "co-opetition", according to which Fintech and banks are both able to compete and cooperate [14]. It is frequent practice for banks to internalize Fintech by buying it, so both "converge towards a common market, with co-opetition strategies that reduce conflicts of interest and other governance concerns. This strategic convergence is also catalyzed by the very fact that banks are digitizing their business models, thus reducing their atavistic differences" [14].

Fintech is the most cutting-edge technological innovation in the field of finance. Although most Fintech is specialized in one market segment, it can create value in every field of finance, using different business models, such as: payments, wealth management, crowdfunding, lending, and capital market business models [17]. They also use various tools, such as "cryptocurrencies and blockchain, new digital advisory and trading systems, artificial intelligence and machine learning, peer-to-peer lending (P2P), equity crowdfunding, and mobile payment systems" [22]. Currently, M-banking (mobile banking) and digital payments are the most popular Fintech solutions, with growing significance due to contactless pandemic prescriptions [14].

Fintech is quite disruptive because of its great innovations for the financial system and other infrastructure, which affect many other areas, such as the economy, society, and the energy sector [22]. Furthermore, Fintech has several effects on social, environmental, and ecological benefits in promoting the use of funds for energy and environmental projects, as well as the construction of renewable energy and environmental infrastructure, "leading to environmental and ecological development by providing cheap and adequate financing" [22].

To summarize, Fintech offers new ways of doing business in financial markets through the implementation of platforms, thanks to "technological implementation, related digital economy business models, and integrated services from different areas", providing "offerings beyond the traditional banking boundaries" [17]. Moreover, technology is creating value in financial services, as costs are being dramatically cut (for instance, branchless 
customers do not need to spend time or energy going to the bank), revenues are increasing, because banking is available anytime and anywhere, and transactions are faster [14].

The main purpose of this paper is to research the relationship between Fintech and sustainability, analyzing the particular case of two different Fintech initiatives: "Clarity AI" [23], a technological platform aimed at aligning financial portfolios with ESG criteria, and "Pensumo" [24], which is linked to consumption and savings for pension plans. Specifically, the effect of greenwashing in Fintech companies and the possibility of using Fintech to promote sustainability will be analyzed, and how "Clarity AI" and "Pensumo" can contribute to this goal will be discussed. A set of recommendations and improvement measures will be proposed for apps related to sustainability, corporate social responsibility (CSR), and greenwashing, all via a literature review and case study approach.

This paper contributes to a global view of the subject by harmonizing theoretical literature about Fintech, the digital transformation context, and sustainability, as well as presenting several practical examples that consider sustainable and environmental concerns. Furthermore, the paper proposes a wide range of improvement measures and emphasizes the importance of consumer protection in the digitization and financial context.

The paper is organized as follows: first, the materials and methods used in the research will be explained; then, the Fintech and sustainability research results will be analyzed, paying particular attention to two Fintech platforms (Clarity AI and Pensumo). Proposals for improvement will then be discussed, and conclusions will be drawn.

\section{Materials and Methods}

This paper will analyze and study the relationship that exists between Fintech and sustainability via a fundamentally theoretical and descriptive methodology, with a review of the literature and several current Fintech examples.

To conduct the research, this paper builds upon a number of articles and reports, selected mainly from SSRN and the Sustainability journal, as is the case with Moro-Visconti, R.; Cruz Rambaud, S.; López Pascual, J., Sustainability in FinTechs: An Explanation through Business Model Scalability and Market Valuation. Sustainability 2020, 12, 10316. These authors firmly believe that Fintech plays a key role in the quest for sustainability.

These articles pose several issues related to greenwashing, sustainability, and Fintech from a general perspective, offering examples of currently sustainable Fintech, as seen in Table 1.

Two interesting reports from Afi and Spainsif have been used for further introductory information.

In addition to these academic resources, several Fintech websites were visited for actual examples, and the sites of Pensumo and Clarity AI were used to provide an in-depth description of Fintech. Other Fintech websites visited are listed in the References section. (The Pensumo Brochure was a useful tool in describing Fintech).

Table 1. Literature Review.

\begin{tabular}{|c|c|}
\hline Section & Articles \\
\hline Introduction & $\begin{array}{r}\text { de Freitas Netto, S.V.; Sobral, M.F.F.; Ribeiro, A.R.B.; Soares, G.R.L. Concepts and forms of greenwashing: a } \\
\text { systematic review. Environmental Sciences Europe 2020, 32(19). } \\
\text { Gräuler, M.; Teuteberg, F. Greenwashing in Sustainability Communication-A Quantitative Investigation of } \\
\text { Trust-Building Factors. 2014. } \\
\text { Pimonenko, T.; Bilan, Y., Horák, J.; Starchenko, L.; Gajda, W. Green Brand of Companies and Greenwashing } \\
\text { under Sustainable Development Goals. Sustainability 2020, 12(4), } 1679 . \\
\text { Delmas, M.A.; Burbano, V.C. The Drivers of Greenwashing. California Management Review 2011, 54(1), 64-87. } \\
\text { Gräuler, M.; Teuteberg, F. Greenwashing in Online Marketing-Investigating Trust-Building Factors Influencing } \\
\text { Greenwashing Detection. 2014. } \\
\text { Badía, G.; Cortez, M.C.; Ferruz, L. Socially responsible investing worldwide: Do markets value corporate social } \\
\text { responsibility? Corporate Social Responsibility and Environmental Management 2020, 27, 2751-2764. } \\
\text { Badía, G.; Ferruz, L.; Cortez, M.C. The performance of socially responsible investing from retail investors' } \\
\text { perspective: international evidence. International Journal of Finance E Economics 2020. }\end{array}$ \\
\hline
\end{tabular}


Table 1. Cont.

\begin{tabular}{|c|c|}
\hline Section & Articles \\
\hline Results & 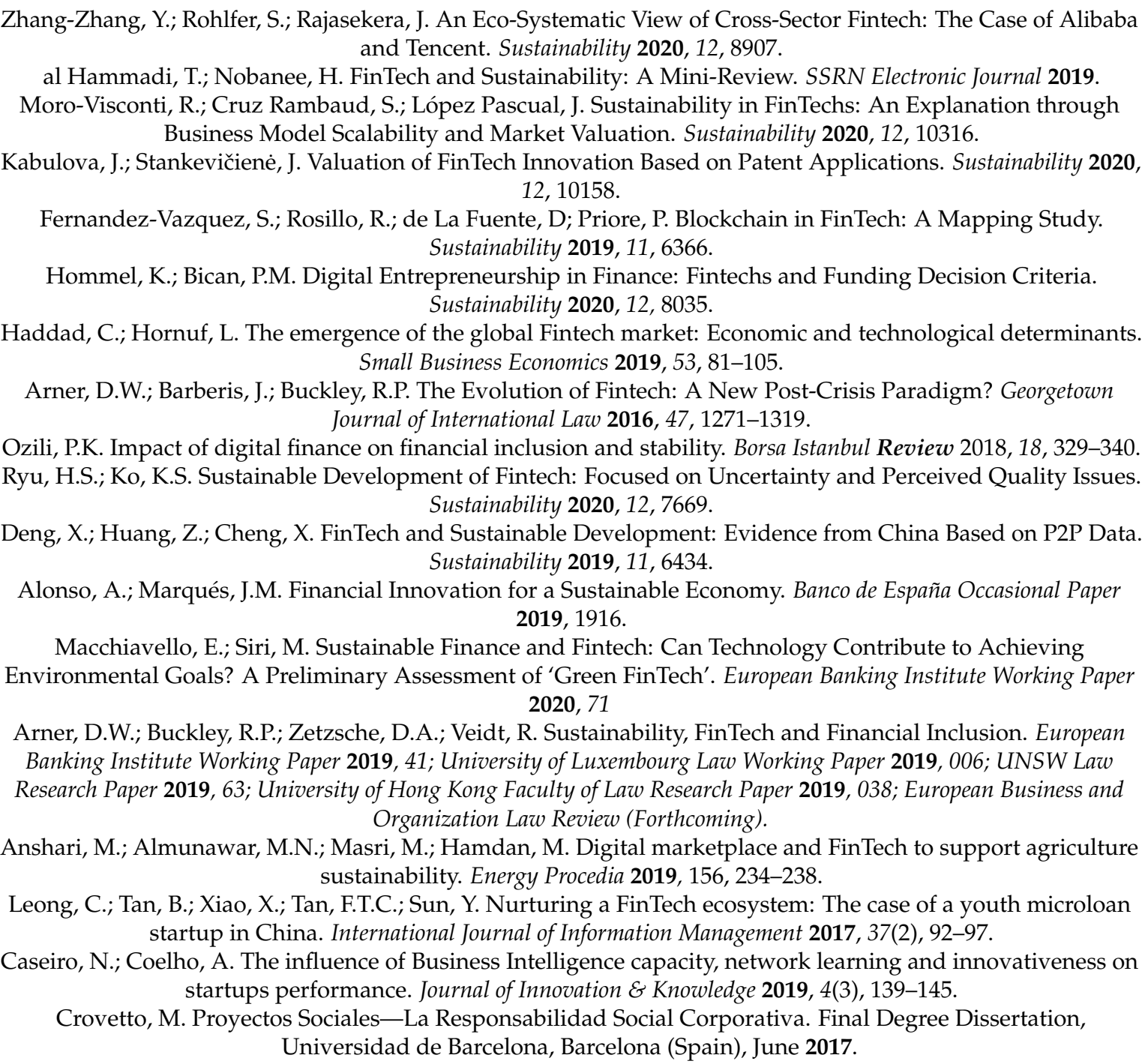 \\
\hline Discussion & $\begin{array}{l}\text { Macchiavello, E.; Siri, M. Sustainable Finance and Fintech: Can Technology Contribute to Achieving } \\
\text { Environmental Goals? A Preliminary Assessment of ‘Green FinTech'. European Banking Institute Working Paper } \\
\text { 2020, 71. } \\
\text { Moro-Visconti, R.; Cruz Rambaud, S.; López Pascual, J. Sustainability in FinTechs: An Explanation through } \\
\text { Business Model Scalability and Market Valuation. Sustainability 2020, 12, } 10316 .\end{array}$ \\
\hline
\end{tabular}

\section{Results}

\subsection{Fintech and Sustainability}

In recent years, considerable progress has been made in the areas of both Fintech and sustainability [14]. The financial sector plays a key role in the challenge to mitigate climate change, one of the primary risks facing our society in the coming decades. In this context, according to Moro-Visconti, Cruz Rambaud, and López Pascual, "sustainability has grown from a niche preoccupation for business to a mainstream concern" [14], and the financial sector has the task of financing the investments needed to transform our economy into a more sustainable one [25]. There are various initiatives in the private financial sector aimed at introducing "sustainability" into its decision-making process to "achieve a balance sheet with a smaller carbon footprint and to develop a business strategy aligned with responsible investment principles and international standards" [25]. These new financial services 
relating to sustainability are provided by both traditional suppliers and, above all, Fintech. It must be noted that the COVID-19 pandemic has demonstrated the existing link between sustainability, finance, and technology, since all countries have been urged to re-think the traditional models and to rely more heavily on technology and sustainability [26].

The development of new technologies has transformed the financial sector, and climate risk management is an important part of this transformation. Furthermore, sustainability criteria may play an important role in all these changes. Certain initiatives are being increasingly used, such as applications that employ artificial intelligence techniques to monitor the sustainability metrics cited in firms' annual reports and financial statements [25].

Although technology is not often associated with environmental goals, Fintech shows coherence and continuity with the ESG world, aimed at a "more inclusive, ESG-resilient, circular, and environment-friendly financial system supporting sustainable development". In fact, "the G-20 has included "Sustainable digital finance" as one of its 2030 work-streams, and the UN, since 2016, has been studying the link between Fintech and Sustainable development" [26].

Digital finance and Fintech both play a part in SDG achievement. One of the ways in which they do so is by enhancing the allocation of existing financial resources to support sustainable development, which occurs through "business models, incentives, policies, and regulations to redirect financial resources globally and in individual countries to provide SDG-related finance". Some examples of this process include ESG and socially responsible investment (SRI) and the significant growth of ESG-related financing in the EU, China, and Japan [27].

The authors of [14] state that Fintech "could help accelerate the development of green and inclusive financial markets and help realign finance to support sustainable development", as "it offers the prospect of quickening the integration of the financial system with the real economy, which will in turn enhance opportunities for greater decentralization and increased participation".

Moreover, the traditional barrier between developed economies and emerging markets is being lowered thanks to the rapid digitization and development of the Fintech industry. Thus, Moro-Visconti, Cruz Rambaud, and López Pascual state that Fintech has "the potential to mobilize green finance and, for instance, enable poorer people around the world to access innovative clean energy projects" [14]. In addition, these authors believe that Fintech "can unlock greater financial inclusion for new businesses that will deliver both impact and financial returns; mobilize domestic savings at scale by providing channels or platforms for retail investors to access impact investing opportunities; collect, analyze, and distribute information on both financial performance and impact performance for better economic decision-making, regulation, and risk management; and provide financial markets with the level playing-field and market integrity needed for long-term sustainable investment" [14].

One of the main fields of collaboration between Fintech and sustainable finance is crowdfunding, which involves either individuals or enterprises being provided with a large number of small amounts of money from other users via an online platform. Thus, green crowdfunding platforms and apps can help environmentally sustainable firms obtain finance and resources in a faster, cheaper, and more affordable way. In addition, these green crowdfunding platforms offer investors the chance to invest their money in sustainable initiatives [26].

Some examples of this are the following: "Abundance" [28] (UK), which allows investments in renewable energy projects and in generating and selling low-carbon electricity, having set up a marketplace where users can buy or sell financial instruments previously issued on the platform; "Ecomill" [29] (Italy), which promotes online equity investments to low-environmental impact projects and local renovation; and Lendosphere [30] (France), which provides loans from individuals for enterprises in the renewable energy sector [26].

In addition, blockchain technology has great potential in the sustainable finance sector. In fact, tokens are usually used to reward contributions to lower carbon emissions or 
other green behaviors, thus creating incentives for the use of solar panels. For instance, Drop in the Ocean [31] (Switzerland) is a platform that brings together individuals and businesses and rewards responsible behavior with a virtual currency, which can be used to buy services or products from participating businesses. Climatrade [32] (Switzerland) has created a market in carbon credits represented by tokens, which can be used to offset carbon emissions by buying from mitigation projects. Similarly, SolarCoin [33] rewards solar energy producers with coins that can be exchanged, used in participating businesses, or traded in market exchanges; and Power Ledger [34] (Australia) has created a trading platform based on blockchain technology where residents can trade solar energy [26].

Then, artificial intelligence (AI) and big data analytics are used to collect and process information on companies and their environmental behavior. For instance, RepRisk [35] (based in Switzerland but with a global reach) uses both artificial intelligence and human analysis to translate big data (not only publicly disclosed information but also satellite data), in twenty languages, into research and metrics, evaluating the ESG risks of listed and non-listed companies [26]. Sustainalytics [36] (Netherlands) uses big data and AI for the cheaper incorporation of ESG considerations into investment decision-making [26]. Other initiatives are Your SRI [37], which uses traditional financial data, ESG data and carbon data to automatically determine a fund's ESG score and its carbon footprint [26], and APG (Netherlands), which [38] "has scanned more than 10,000 companies in twelve months for sustainability contributions, while Ecochain [39] software maps the entire life cycle of companies, including their environmental footprint, allowing the creation of carbon savings certificates digitally" [26].

All the tools and platforms mentioned above are summarized in Table 2.

Table 2. Green Fintech fields/tools and main platforms.

\begin{tabular}{cc}
\hline Fields/Tools & Platforms \\
\hline Crowdfunding & Abundance (UK) \\
Ecomill (Italy) \\
Lendosphere (France)
\end{tabular}

Prepared by the authors, based on [26].

In addition to these platforms, it is necessary to highlight the important role of Fintech in the process of transforming agriculture's business process into a more sustainable one. In this context, Fintech offers farmers different ways of obtaining funding, through crowdfunding and digital payment systems, as well as a digital marketplace that can connect "all actors (farmers, landowners, investors, and consumers) into a platform that can promote transparency, empowerment, resourcefulness, and public engagement in agriculture". This strategy contributes to increasing competition among suppliers and improves the sustainability of agricultural products, since customers are able to see prices, compare products, and be aware of their sustainable features, paying directly using Fintech [40].

Other Fintech, such as 007fenqi in China, gives young people greater access to financial products and services, as they are often excluded from most financial services. 007fenqi not only offers microloans to college students but is centered on their needs and offers services in four areas: spend, loan, earn, and invest. For instance, it offers them assistance in finding 
part-time jobs or internship opportunities "so that they can earn an income and make their repayments on time", and "one of its main purposes is to educate Chinese youth about the importance of financial responsibility" [41].

To summarize, it is possible to verify that "sustainable Finance and Fintech sectors present many common aspects, and their linkage offers interesting synergies and great potential" [26]. In fact, Fintech can make the overall financial business more resilient and sustainable, as it promotes both sustainable development and green finance [14]. "Financial technology is also an excellent tool to build sustainable communities and lift poverty, as it promotes responsible consumption and production" [14]. In addition, "Fintech itself is environment-friendly, facilitating green finance, reducing asymmetric information for investors, promoting efficiency, valuing nature's assets, and backing sustainable lifestyles inspired by a sharing or circular economy" [14].

Two Fintech initiatives related to sustainability, socially responsible investment, and green behavior are described and examined below. The first is Clarity AI, a global Fintech, which operates in the artificial intelligence sector, and the second is Pensumo.

Among the reasons for the choice of Clarity AI are the great potential of the artificial intelligence sector, as well as the numerous awards that this Fintech has won in recent years. Moreover, it is worth noting its unique methodology, which can have a significant impact on the decision-making process of investors and could be extended to other areas.

As far as Pensumo is concerned, there are many reasons that justify the choice of this Fintech. Firstly, it is a financial services Fintech company that we know in depth because of professional reasons. Secondly, it has received many national, European, and international awards and has an excellent track record of growth. In addition to considering sustainability from a financial perspective, it seeks to promote responsible behavior and attitudes among consumers by rewarding certain actions and proposes an original method to complement the pensions system.

\subsection{Clarity AI}

Clarity AI [23] is a global Fintech company founded by Rebeca Minguela in 2017, with offices in the USA, UK, and Spain and clients all over the world.

Clarity AI is a "societal impact rating agency and tech company offering a software solution for investors to optimize the societal and environmental impact of their investment portfolios". It allows investors to manage the social impact of their portfolios through a technological platform using big data and machine learning to assess the sustainability and environmental impact of more than 30,000 firms in 198 countries, 187 local governments, more than 200,000 funds, and following 1000 indicators.

The main objective of Clarity AI is to measure the social and environmental impact of companies. Investors often find it difficult to assess the impact of their investments, as there are limited and unreliable data, so it is laborious and expensive for them to draw clear and simple conclusions. Clarity AI offers an easy solution to this problem through its technological platform. It "aggregates multiple data sources and selects the most reliable ones" and "offers the largest coverage of social and environmental impact data about publicly traded securities in the market, with the highest level of reliability and accuracy".

Clarity AI contributes to more socially and environmentally efficient capital allocation. To achieve this goal, it provides decision makers with "the most reliable and comprehensive tools to understand and optimize social and environmental impact, leveraging scientific research and the latest technologies" [23].

Fintech offers an "end-to-end technology solution based on scientific research, quantitative assessment, and global preferences that optimizes the societal impact of investment portfolios" [23]. To do this, Clarity AI enables investors to import or create a portfolio of securities and either select their social and environmental personal preferences or allow Clarity AI to apply the global standard. Then, it shows investors the social and environmental impact and the financial performance of the portfolio they have created. This portfolio can be rebalanced by considering Clarity AI's recommendations on how to opti- 
mize social and environmental impact and financial performance. As a result, investors have a rebalanced portfolio based on their initial preferences, interests, and conscience, but by considering social and environmental issues and leveraging multiple sources of data and information.

It must be noted that Clarity AI has a unique and proprietary societal impact methodology, which measures and assesses not only how companies behave but also, and more importantly, the social impact of these companies. This Fintech company believes the traditional ways of financial markets to evaluate and measure the impact of companies on society, which consists of using ESG indicators, is limited, because it considers only how companies behave in the three dimensions of ESG (environmental, social, and governance), without considering the relevance to society of the products and services offered by these companies. With its methodology, Clarity AI expands the ESG framework to "clarify the real impact of the companies on society" [23].

An important part of the mission of Clarity AI is to communicate "the importance of understanding and optimizing societal impact, leveraging the latest technologies". In recent years, this revolutionary Fintech company has received wide recognition for its positive impact and innovative approach and was selected as a 2020 Technology Pioneer by the World Economic Forum. In addition, it was selected by the Harvard Innovation Lab "as one of the most innovative projects in the United States to participate in a one-year research project to develop the social impact measurement methodology". It has also gained funding from Horizon 2020 and the European Union Research and Innovation program and has been ranked among the top 14 start-ups with global impact from the more than 1900 candidates by Impact Growth.

This is an example of business intelligence (BI), since it uses technology to process information in order to improve decision making and to predict the behavior of portfolios and companies with a degree of certainty. Clarity AI converts data into useful knowledge and then makes better and faster decisions. In fact, this knowledge is a source of competitive advantage for Clarity AI, as there is a positive relation between business intelligence characteristics and innovation in startups [42].

\subsection{Pensumo}

The Fintech Pensumo (Pension by Consumption) was created by José Luis Orós. Its main objective is to make micro-contributions to a private pension plan through daily consumption, and its vocation is a collaborative and responsible economy to obtain social benefit.

It is registered in Spain and Europe under the corporate name "Plataforma de Fidelización PENSUMO S.L." and aims to introduce the so-called "Pension by Consumption" into Spain, a new (non-equity) savings model that links the daily actions of consumption, recycling, sports activities, and good practices as a citizen, for example, with the receipt by users of economic micro-contributions for a lifetime, in a savings plan that grows as these actions are carried out for as long as money accumulates in the plan [43].

Due to the aging of the European population, the decrease in the number of Social Security contributors, and the inability of the general population to save enough, the viability of the pension system is in danger. In this context, the European Union's White Paper on Pensions proposed improving private savings plans and developing plans to promote long-term saving by the public through the introduction of certain incentives. Along the lines of these European recommendations, Pensumo provides an innovative tool to supplement pension savings.

According to several market studies and the data obtained in the two pilot years with almost 2000 users and 100 stores, it was estimated that $6.5 \%$ of the Spanish population over the age of 18, that is, around 3 million people, will be Pensumo users. These users are mainly women between the ages of 35 and 40 who shop at service stations, hairdressers, and sports stores [43], who are concerned about their future but lack the ability to save on a regular basis. 
Thus, Pensumo can be said to offer a unique savings system. The app and the CRM that controls the data must be downloaded and, from then on, customers go about their everyday activities (shopping, recycling, sports activities, cultural consumption, road safety, and volunteering, among others) and justify them via the app, so that these actions are measured and rewarded by businesses and partners. Thus, consumers can use their smartphone as an instrument to save from contributions given as an incentive and in return for sustainable, responsible, and ethical purchases made or activities performed. In short, it is a system of savings generated from a set of responsible actions measured via cellphones.

There are two ways of saving using Pensumo: either purchases in affiliated stores or by taking part in challenges, as the app promotes campaigns that motivate responsible and collaborative actions (e.g., recycling, road safety, and "I go by bike"), whose conditions are indicated in detail for each campaign. For purchases, each business has a different contribution percentage, whereas for challenges, contributions are fixed but can vary from one challenge to another.

To justify the purchases, all that is required (in the app) for physical commerce is a photo of the purchase receipt from the associated stores. Meanwhile, online purchases must be made through the app, and the user then sends a confirmation email [24]. In addition, contributions to the savings plan are variable and are limited by time and the number of activities, to ensure users do not consume too much in order to receive incentives.

Currently, many of the activities proposed by Pensumo are aimed at sustainability; that is, they contribute toward developments capable of meeting current needs, without jeopardizing the resources and possibilities of future generations. Examples of this are purchases made in local stores, using bicycles to move around the city, and recycling, as all these activities are considered sustainable.

Every day, small amounts of money (cents, most of the time) accumulate in the savings policy guaranteed for each consumer. As indicated above, the consequence of the widespread use of this system by most people would be the emergence of a new type of pension system. This would supplement that of the Social Security and would be unique insomuch as it is free and voluntary for the beneficiaries [44], as indicated above.

Whenever a challenge is completed or a purchase made by consumers in an establishment associated with Pensumo (both online and physical), micro-contributions to their savings plan are made, which means they are saving for their future, as the cents accumulated generate the profitability determined in the final product they are invested in. Currently, this final product is a guaranteed savings plan with a $0.5 \%$ annual return [44]. In addition, more savings can be made by making extraordinary contributions added to the existing savings or by disseminating the app to new users (such as friends or family) and new businesses, as this also has its benefits. Moreover, Pensumo users can check their accumulated savings on the website and in the app.

The money accumulated is managed by the insurance company Allianz in an open collective insurance policy, with the sole requirements being to be of legal age and to have a confirmed registration. This policy has no maintenance costs and does not require the user's account number until the moment the money is redeemed [24].

Redeeming the money can be requested by the user through the website by downloading and completing a PDF request form stating the account number where the money is to be deposited. The Allianz product conditions specify that the money can be redeemed in 5-year liquidity windows, without penalty. The money can also be redeemed after the first year, although with a corresponding penalty [24]. In short, consumers cannot use or dispose of the money whenever they wish but must wait for the aforementioned 5-year liquidity windows or pay a penalty if they redeem it after the first year, which may be inconvenient for many users. In addition, it must be considered that this penalty implies a cost, whose amount should be known and compared with the savings in order to assess the actual profitability obtained by the consumer.

The main income for this Fintech company comes from a 1\% commission on sales. Pensumo does not have fixed fees, but each business decides the percentage of each 
purchase made by the user. This varies according to the type of business and its features, and the Fintech company receives $1 \%$ of that assigned percentage, allocating the rest to user savings plans. Thus, there is no other payment, as businesses pay no membership, maintenance, or withdrawal fees.

Pensumo also obtains income from the development of platforms for large companies and groups, through the creation of benefit systems for groups of workers and their families. Pensumo develops "ready-to-use" ICT platforms, adapted to the characteristics of each group and the expected objectives. This system "can be complementary to other existing incentives in the company that aim to guarantee the future well-being of the participants". Furthermore, "the maximum costs per employee are established by the company, which can decide the actions to be rewarded itself or can coordinate them with Pensumo" [44]. These actions may range from employee training or recycling to commuting by bicycle or participating in company activities. "The cost for the company is estimated at $€ 20$ to $€ 30$ per worker per month, and the accumulated cost of a personal employment savings plan can exceed $€ 30,000$ in 25 years" [44].

In short, for small businesses, Pensumo is a quick, simple, and different loyalty tool in which "the savings received by the client are real money, as opposed to gift cards and other discounts" [24]. It also represents a way of differentiating itself from the leading companies in the sector.

Considering all the above, this is a new business dimension that pays less attention to the short term and is also concerned with sustainability. Some examples of this are activities rewarded by Pensumo, as they involve local commerce, which eliminates unnecessary travel and reduces the use of vehicles, as well as activities aimed at taking care of the environment, such as recycling or cycling, thus avoiding the consumption of fuel and emission of pollutants. For example, through the "Reciclo y sumo" challenge ("I recycle and contribute"), contributions can be obtained by recycling: "through photos or QR codes, and by setting a limitation of visits to the container, an awareness action linked to savings is achieved" [44].

For many consumers, concepts such as ethical savings, socially responsible investment, recycling, the collaborative economy, and fair trade and local trade are becoming increasingly common. Thus, "Pensumo creates a community between companies and users, encourages the habit of saving, and also encourages values such as sustainability and the like. Pensumo is a clear example of a socially responsible company, and, moreover, it is the future of pensions" [43], as it is a free and voluntary savings system.

Perhaps due to all these considerations, Pensumo was selected in 2017 and 2019 as one of the Spanish projects for the Horizon 2020 Project, funded by the European Commission. It also received recognition as an Innovative Small and Medium-sized Enterprise (SME) by the Ministry of Industry and Competitiveness for the period 2018 to 2021. It has also received several awards and certifications of excellence since 2014. In 2018, it was awarded the Aragonese Prize for Social Entrepreneurship and was considered the Best Startup of 2018 in the "El Español" Digital Awards. In 2019, it received the Collaborative Economy Award "Lánzate" from E.O.I and Orange, and the EU-GIVE Award in Brussels, also in the context of the Collaborative Economy. Finally, in 2020, it was recognized by the Spanish "Red Española Pacto Mundial" and Rafael del Pino Foundation for its contribution toward the Sustainable Development Goals (SDG).

In conclusion, Pensumo aims to promote customer loyalty and corporate social responsibility (CSR) from a social and innovative perspective, by saving for the future.

Some of the main features of Clarity AI and Pensumo are summarized in Table 3. 
Table 3. Main features of Clarity AI and Pensumo (summary).

\begin{tabular}{|c|c|}
\hline Clarity AI & Pensumo \\
\hline $\begin{array}{l}\text { Global reach. } \\
\text { tech company. } \\
\text { It is a societal impact rating agency and } \\
\text { It offers a software solution for investors to } \\
\text { optimize the societal and environmental } \\
\text { impact of their investment portfolios. } \\
\text { It uses big data and machine learning to assess } \\
\text { sustainability and environmental impact. } \\
\text { It contributes to more socially and } \\
\text { environmentally efficient capital allocation. } \\
\text { It provides decision makers with the most } \\
\text { reliable and comprehensive tools. } \\
\text { Possibility of creating personalized portfolios. } \\
\text { Unique and proprietary societal impact } \\
\text { methodology. }\end{array}$ & $\begin{array}{l}\text { Spanish Fintech company. } \\
\text { It is a system for generating savings by } \\
\text { carrying out a set of responsible actions } \\
\text { measured via cellphones. } \\
\text { Its main objective is to make } \\
\text { micro-contributions to a private pension plan } \\
\text { through daily consumption and } \\
\text { sustainable behavior. } \\
\text { It promotes several campaigns that encourage } \\
\text { responsible and collaborative actions. } \\
\text { The contributions to the savings plan are } \\
\text { variable and are limited in time and the } \\
\text { number of actions. } \\
\text { The money accumulated by using Pensumo is } \\
\text { managed by the insurance company "Allianz" } \\
\text { in an open collective insurance policy, which } \\
\text { has no maintenance costs. } \\
\text { It is possible to redeem the money in 5-year } \\
\text { liquidity windows without any penalty. } \\
\text { Businesses pay no membership, maintenance, } \\
\text { or withdrawal fees. } \\
\text { It creates benefit systems for groups of workers } \\
\text { and their families. }\end{array}$ \\
\hline
\end{tabular}

Personal research.

\section{Discussion}

Having examined the relationship between Fintech, sustainability, and environmental development and after analyzing two important examples of sustainable Fintech platforms, both general and specific proposals for improvement to make these Fintech initiatives even greener and more environmentally friendly will be discussed. These proposals must consider consumers, as it is essential for them to be informed and aware of the behavior of the businesses they deal with regularly, as well as for the bonds and stocks they invest in.

\subsection{Proposals for Commercial Solutions}

On the one hand, although Clarity AI already uses big data and machine learning to assess the sustainability and environmental impact of companies and investments, we believe it would be advisable to offer investors complete information on the behavior and impact of different companies. This is because it is important to show investors the social and environmental impact of their portfolios and recommend how they should optimize this impact and performance; it is also essential to explain the reasons why they should or should not invest in a specific fund or company.

This could be achieved by including a descriptive section in the platform on the behavior, relevant data, and analysis of the sustainability reports, and even news on the most important companies and funds. Considering this kind of information, users would be able to understand the reasons why they are being advised to invest, or not, in a certain firm, stock, or fund. In addition, it would be essential to keep investors informed of recent environmental and social scandals, perhaps by creating an "alarm" or notifications system that would provide them with more timely and accurate news.

On the other hand, even though Pensumo already takes into account issues such as sustainability, the environment, and recycling, and despite the fact that CSR is a basic and essential requirement for all companies wishing to be part of its network of collaborators, we believe it is difficult to verify whether company behavior is actually sustainable or whether the company is merely greenwashing. 
Thus, we believe several improvements could be made to the app, so that it directs consumers towards even more responsible behavior, by taking a step further in respecting the environment and achieving a more sustainable society.

In addition to the behavior and values Pensumo rewards, such as local commerce, volunteering, recycling, and/or maintaining an active and healthy life, we believe this Fintech company could promote better information for users about the goods and services they purchase and the activities of the brands they normally consume. Thus, an aware, well-informed consumer who chooses companies and brands that respect society and the environment should be rewarded and not only in the field of local commerce but in all the areas of a consumer's life.

We believe that an improvement to the app would be to encourage the consumption of goods and services from brands and companies that are truly respectful towards the environment, and with each purchase made in these companies, the consumer using Pensumo would accumulate new savings in their pension plan. Thus, fully responsible and informed consumption would be promoted not only in local establishments or businesses but also in all companies with which the consumer interacts.

For example, consumers could try to inform themselves about the social and environmental behavior of their electricity supply company, their bank, their telephone company, their internet service provider, their home furniture manufacturers, the hotel chains where they spend their holidays, and the restaurants where they go for lunch or dinner.

However, it is difficult to know if a company is behaving responsibly and if its products and services are truly ecological or environmentally friendly. As explained in the Introduction, there are currently many companies involved in deceptive practices to make potential customers believe they respect the environment, when in fact this is not the case. Thus, corporate social responsibility (CSR) reports should include information about known greenwashing practices.

One possible improvement for Pensumo could be the introduction of a QR code reader in the current app. This could scan the company codes with which consumers interact, codes that would link to CSR or Sustainability Reports of specific companies. Then, after analyzing these reports, consumers will be able to determine whether the company they are about to carry out a transaction with is truly a responsible company. Reading the QR code could allow for company press releases to be traced, to ascertain whether they have been involved in any type of scandal. This would allow greenwashing factors to be known, and the potential investor would find out how sustainable the company actually is and how it meets CSR criteria. It might also be interesting for the app itself to suggest more ecological or sustainable alternatives to particular companies and products.

\subsection{General Proposals for Sustainability in the Fintech Sector}

In general, to promote a more environmentally informed society, more standardization would be required in both the format and metrics of ESG reporting and sustainability reports. Thus, ESG reporting, benchmarking, and rating could be improved with new technologies such as AI, big data analytics, and DLT. These tools could compile information from disparate sources (including articles), "processing of large amounts of data (even non-standardized and unstructured) about companies' social and environmental impacts, as well as translation in more standardized and comparable data, with positive effects on pricing accuracy and the level of reliability of ESG data" [26]. In fact, a large amount of data from "NGOs, specialized websites, and satellites (publicly available through the European Union's Copernicus network and the US Landsat network) might be combined and processed by AI to track air pollution and emissions by single power plants and, more generally, double-check information provided by companies" [26].

Another important point to consider is Fintech regulation, since, according to MoroVisconti, Cruz Rambaud, and López Pascual, this will be the key to determining the kinds and number of Fintech companies entering the industry and who the dominant players are [14]. 
In 2018, the European Commission adopted the "Financing Sustainable Growth" Action Plan to redirect private capital towards more sustainable investments and the Fintech Action Plan, with the aim of creating a harmonized and dynamic European framework for Fintech. The Commission released a package of proposals to implement ESG considerations in the decision-making process of investors, including "a Regulation with criteria to determine the environmental sustainability of economic activities (Taxonomy Regulation) and therefore clarify for investors what activities can be considered to be "green" and used as a basis for standards and labels for sustainable financial products" [26]. The final text of this regulation was signed by the Parliament and Council on June 18, 2020, with the aim of reducing greenwashing and market and regulatory fragmentation among the Member States. "The Commission is also evaluating the opportunity of introducing, also for non-financial information, a European Single Electronic Format (ESEF), as for financial reporting, of issuers in regulated markets" [26].

In addition to all these measures and regulations, we believe it would be appropriate to continue improving European and Global regulation of Fintech companies and sustainability criteria to enable investors and consumers, in general, to "access adequate non-financial information from companies (limiting companies' discretion and wide variations in standards) while at the same time reducing the unnecessary burden on companies" [26] and aligning those legal documents with EU taxonomy.

It will be important in the near future to adapt company reporting and transparency, accounting standards and rules, sustainability research and ratings, labeling tools for financial assets and products, and corporate governance. Moreover, it will be necessary to increase "opportunities for citizens, financial institutions, and corporates to actively engage in the sustainable finance debate regarding green investments and investor protection, through varied actions such as the development of guidelines for financial advisers, programs to raise awareness and financial literacy about sustainability, green securitization, and the deployment of digital technologies in the sector" [26].

To conclude, there are still many regulatory issues related to customer and consumer protection to be resolved. More specifically, consumers need regulation regarding data protection, accessibility, portability and interoperability, wrongful assessments, opacity and discrimination, and financial exclusion [26]. Therefore, institutions all over the world must go ahead with their regulatory processes and frameworks to improve consumer protection and information. The challenge for regulators will be, ultimately, to "keep a level playing field that strikes the right balance between fostering innovation and preserving financial stability, and consumer protection" [14].

\section{Conclusions}

\subsection{Theoretical Contributions and Implications}

As has been discussed in this paper, the current concerns over global warming and environmental issues, as well as the importance of corporate social responsibility (CSR) and environmental, social, and governance (ESG) factors have led to the emergence of different kinds of behavior (e.g., greenwashing) and finance trends and tools (such as socially responsible investment and the use of sustainable Fintech initiatives) due to a willingness by investors to incorporate not only financial criteria but also non-financial attributes into their investment decisions.

In the current environment, the financial sector plays a key role in fighting climate change, as it has the task of financing the investments needed to transform our economy into a more sustainable one. The new financial services relating to sustainability are provided by both traditional suppliers and, above all, Fintech companies, aimed at improving, developing, and automating financial services.

Fintech companies are becoming increasingly popular, with great expectations for growth, and they are used to assist and support firms, investors, and customers in managing their financial activities, using specialized applications and software. Furthermore, the Fintech industry is a driving force for sustainable economic growth with several effects 
on social, environmental, and ecological benefits. As far as environmental and ecological development is concerned, Fintech can promote the use of funds for energy and environmental projects, as well as the construction of renewable energy and environmental infrastructure.

Fintech shows consistency and continuity with ESG criteria through the use of tools such as crowdfunding, big data analytics, blockchain technology, and artificial intelligence. As indicated above, sustainable finance and Fintech have many shared aspects, and Fintech can make financial business overall more sustainable, as it promotes green finance.

Throughout this paper, the strategic perspective of Fintech has been described, and it has been possible to study the relationship between Fintech and sustainability by providing an extensive review of the literature. Furthermore, the theoretical scope has been applied to some examples of real, sustainable Fintech, which show ways to implement sustainable behaviors and to promote green investment.

The paper emphasizes the need for greater standardization in both the format and the metrics of ESG reporting and sustainability reports, as well as the implementation of different systems and technologies to detect and prevent greenwashing practices. This would direct consumers towards even more responsible behavior by taking a step further in respecting the environment and towards a more sustainable society.

\subsection{Implications for Practice}

Theoretical implications have been put into practice by analyzing and describing two cutting-edge Fintech companies: Clarity AI and Pensumo.

The analysis of these two important Fintech platforms leads to the conclusion that this kind of app and platform still needs improvements to keep consumers, users, and investors informed and aware of the behavior of the businesses they usually deal with, as well as of the bonds and stocks in which they invest. In this context, this paper gives some practical advice and recommends improvement measures in order to optimize the platforms' performance from the perspective of consumer information and protection.

\subsection{Future Research Direction}

Future research will focus on European and global regulation frameworks. They play an essential role, but it is still necessary to resolve many problems related primarily to customer and consumer protection. Thus, future research into the impact of user information and protection on sustainable Fintech companies is needed.

It will be necessary to study different examples of sustainable Fintech and seek out their weaknesses in order to propose new improvement measures. What is more, it will be essential to design a plan for each platform so as to put all these measures into practice and to modify their apps by taking into account all the considerations discussed throughout the paper.

Author Contributions: Conceptualization, L.F.A. and C.C.V.; investigation, C.C.V.; resources, C.C.V.; data curation, C.C.V.; writing—original draft preparation, C.C.V.; writing-review and editing, L.F.A. and C.C.V.; supervision, L.F.A. All authors have read and agreed to the published version of the manuscript.

Funding: This research received no external funding.

Conflicts of Interest: The authors declare no conflict of interest.

\section{References}

1. Nielsen. Available online: https://www.nielsen.com/eu/en/press-releases/2015/consumer-goods-brands-that-demonstratecommitment-to-sustainability-outperform/ (accessed on 7 October 2020).

2. de Freitas Netto, S.V.; Sobral, M.F.F.; Ribeiro, A.R.B.; Soares, G.R.L. Concepts and forms of greenwashing: A systematic review. Environ. Sci. Eur. 2020, 32, 1-12. [CrossRef] 
3. Gräuler, M.; Teuteberg, F. Greenwashing in Sustainability Communication-A Quantitative Investigation of Trust-Building Factors. 2014. Available online: https://www.researchgate.net/publication/261610512_Greenwashing_in_Sustainability_ Communication_-_A_Quantitative_Investigation_of_Trust-Building_Factors (accessed on 7 October 2020).

4. Pimonenko, T.; Bilan, Y.; Horák, J.; Starchenko, L.; Gajda, W. Green Brand of Companies and Greenwashing under Sustainable Development Goals. Sustainability 2020, 12, 1679. [CrossRef]

5. Delmas, M.A.; Burbano, V.C. The Drivers of Greenwashing. Calif. Manag. Rev. 2011, 54, 64-87. Available online: https: / / ssrn.com/abstract=1966721 (accessed on 9 October 2020). [CrossRef]

6. Gräuler, M.; Teuteberg, F. Greenwashing in Online Marketing_-Investigating Trust-Building Factors Influencing Greenwashing Detection. 2014. Available online: https:/ / www.researchgate.net/publication/258507737_Greenwashing_in_Online_Marketing_ -_Investigating_Trust-Building_Factors_Influencing_Greenwashing_Detection (accessed on 9 October 2020).

7. Badía, G.; Cortez, M.C.; Ferruz, L. Socially responsible investing worldwide: Do markets value corporate social responsibility? Corp. Soc. Responsib. Environ. Manag. 2020, 27, 2751-2764. [CrossRef]

8. Badía, G.; Ferruz, L.; Cortez, M.C. The performance of socially responsible investing from retail investors' perspective: International evidence. Int. J. Financ. Econ. 2020. [CrossRef]

9. Foro Español de Inversión Sostenible. Guía de Uso del Estándar de Bono Verde Europeo (EU GBS). 2020. (Spanish Forum for Sustainable Investment. Use Guide for the European Green Bond Standard). Available online: https://www.spainsif.es/wpcontent/uploads/2020/04/webminar-EU-GBS-V6.pdf (accessed on 15 October 2020).

10. Afi. Las finanzas Verdes en el Reino Unido y España: Últimos Acontecimientos y Principales Proveedores de Servicios. Informe final para British Embassy Madrid. 10. (Green Finance in the UK and Spain: Latest Events and Top Service Providers. Final report for British Embassy). 2020. Available online: https:/ / www.afi.es/webAfi/descargas/1996317/1413281/las-finanzas-verdes-enel-reino-unido-y-espana-ultimos-acontecimientos-y-principales-proveedores-de-servicios.pdf (accessed on 15 October 2020).

11. IPCC. Available online: https://www.ipcc.ch/about/ (accessed on 12 November 2020).

12. Zhang-Zhang, Y.; Rohlfer, S.; Rajasekera, J. An Eco-Systematic View of Cross-Sector Fintech: The Case of Alibaba and Tencent. Sustainability 2020, 12, 8907. [CrossRef]

13. al Hammadi, T.; Nobanee, H. FinTech and Sustainability: A Mini-Review. SSRN Electron. J. 2019. [CrossRef]

14. Moro-Visconti, R.; Cruz Rambaud, S.; López Pascual, J. Sustainability in FinTechs: An Explanation through Business Model Scalability and Market Valuation. Sustainability 2020, 12, 10316. [CrossRef]

15. Kabulova, J.; Stankevičienè, J. Valuation of FinTech Innovation Based on Patent Applications. Sustainability 2020, $12,10158$. [CrossRef]

16. Fernandez-Vazquez, S.; Rosillo, R.; de La Fuente, D.; Priore, P. Blockchain in FinTech: A Mapping Study. Sustainability 2019, 11, 6366. [CrossRef]

17. Hommel, K.; Bican, P.M. Digital Entrepreneurship in Finance: Fintechs and Funding Decision Criteria. Sustainability 2020, 12, 8035. [CrossRef]

18. Haddad, C.; Hornuf, L. The emergence of the global Fintech market: Economic and technological determinants. Small Bus. Econ. 2019, 53, 81-105. [CrossRef]

19. Arner, D.W.; Barberis, J.; Buckley, R.P. The Evolution of Fintech: A New Post-Crisis Paradigm? Georget. J. Int. Law 2016, 47, 1271-1319. [CrossRef]

20. Ozili, P.K. Impact of digital finance on financial inclusion and stability. Borsa Istanb. Rev. 2018, 18, 329-340. [CrossRef]

21. Ryu, H.S.; Ko, K.S. Sustainable Development of Fintech: Focused on Uncertainty and Perceived Quality Issues. Sustainability 2020, 12, 7669. [CrossRef]

22. Deng, X.; Huang, Z.; Cheng, X. FinTech and Sustainable Development: Evidence from China Based on P2P Data. Sustainability 2019, 11, 6434. [CrossRef]

23. Clarity AI. Available online: https: / / clarity.ai/ (accessed on 19 November 2020).

24. Pensumo. Available online: https://pensumo.com/ (accessed on 15 September 2020).

25. Alonso, A.; Marqués, J.M. Financial Innovation for a Sustainable Economy. Banco de España Occasional Paper 2019, 1916. [CrossRef]

26. Macchiavello, E.; Siri, M. Sustainable Finance and Fintech: Can Technology Contribute to Achieving Environmental Goals? A Preliminary Assessment of 'Green FinTech'. Eur. Bank. Inst. Work. Pap. 2020, 71. [CrossRef]

27. Arner, D.W.; Buckley, R.P.; Zetzsche, D.A.; Veidt, R. Sustainability, FinTech and Financial Inclusion. Eur. Bank. Inst. Work. Pap. 2019, 41. [CrossRef]

28. Abundance Investment. Available online: https://www.abundanceinvestment.com (accessed on 12 November 2020).

29. Ecomill. Available online: https:/ / www.ecomill.it (accessed on 12 November 2020).

30. Lendosphere. Available online: https:// www.lendosphere.com (accessed on 12 November 2020).

31. My Drop in the Oceans. Available online: https:/ / www.mydropintheoceans.org/home (accessed on 12 November 2020).

32. Climate Trade. Available online: https:/ / climatetrade.com (accessed on 12 November 2020).

33. Solarcoin. Available online: https:/ / solarcoin.org/ (accessed on 12 November 2020).

34. Power Ledger. Available online: https://www.powerledger.io/about-us / (accessed on 12 November 2020).

35. Reprisk. Available online: https:/ / www.reprisk.com (accessed on 12 November 2020).

36. Sustainalytics. Available online: https://www.sustainalytics.com (accessed on 12 November 2020).

37. Your SRI. Available online: https:/ / yoursri.com/ (accessed on 12 November 2020). 
38. APG. Available online: https://apg.nl/en/ (accessed on 12 November 2020).

39. Ecochain. Available online: https:/ / ecochain.com/ (accessed on 12 November 2020).

40. Anshari, M.; Almunawar, M.N.; Masri, M.; Hamdan, M. Digital marketplace and FinTech to support agriculture sustainability. Energy Procedia 2019, 156, 234-238. [CrossRef]

41. Leong, C.; Tan, B.; Xiao, X.; Tan, F.T.C.; Sun, Y. Nurturing a FinTech ecosystem: The case of a youth microloan startup in China. Int. J. Inf. Manag. 2017, 37, 92-97. [CrossRef]

42. Caseiro, N.; Coelho, A. The influence of Business Intelligence capacity, network learning and innovativeness on startups performance. J. Innov. Knowl. 2019, 4, 139-145. [CrossRef]

43. Crovetto, M. Proyectos Sociales-La Responsabilidad Social Corporativa. Bachelor's Thesis, Universidad de Barcelona, Barcelona, Spain, 2017.

44. Pensumo Brochure. Available online: https://pensumo.com/comercio/ (accessed on 19 November 2020). 